\title{
Effect of Micronutrient Mixture Formulation on Growth, Yield and Quality of Guava
}

\author{
D. Janaki*, S. Prabhu, R. Poorniammal and J. Kannan
}

Horticultural College \& Research Institute, TNAU, Periyakulam -625 604, Tamilnadu, India

*Corresponding author

\begin{abstract}
A B S T R A C T
Guava is one of the important fruit crop cultivated all over India. A guava plant shows micronutrient deficiency which could be responsible for lesser yield and quality. Foliar feeding of nutrients to fruit plants has gained much importance in recent years which is quite economical and obviously an ideal way of evading the problems of micronutrients availability and supplementing the fertilizers to the soil. The present investigation was conducted at Horticultural College \& Research Institute, Periyakulam during 2018-2019. The experiment was raised on well-established orchard of 3 years old Lucknow -49 guava trees which are planted at $3.0 \times 1.5 \mathrm{~m}$ spacing. The experiment was laid out in Factorial Randomized Block Design (FRBD) with five treatments replicated four times with two different grades. The results revealed that the application of $\mathrm{RDF}+$ Enriched $\mathrm{MN}$ Mixture (Soil)@2kg/tree + Foliar spray of MNM@0.3\% ( $\left.\mathrm{T}_{3}\right)$ recorded highest fruit yield of $47.90 \mathrm{t} \mathrm{ha}^{-1}$, followed by $\mathrm{T}_{1}$ recorded next highest fruit yield of $37.60 \mathrm{tha} \mathrm{h}^{-1}$ while the control $\left(\mathrm{T}_{4}\right)$ recorded the lowest of $19.60 \mathrm{t} \mathrm{ha}^{-1}$, The treatment $\mathrm{T}_{3}$ recorded the highest in quality parameters with reducing sugar(8.02\%), non-reducing sugar(6.93\%) and lowest acidity $(0.42 \%)$ Hence application of grade I $\mathrm{RDF}+$ Enriched MN Mixture (Soil)@2kg/tree + Foliar spray of MNM@0.3\% can be advocated in increasing the yield and quality of Guava
\end{abstract}

\begin{tabular}{|l|}
\hline Ke y w o r d s \\
Fruit crop, \\
Micronutrient \\
deficiency, \\
Enriched MN \\
mixture
\end{tabular}

\section{Introduction}

Concept of global village and advances in technology enable exporters to supply markets around the world with high quality product. To compete in domestic as well as foreign market requirements, quality fruit production is becoming a major objective of the day in fruit industry.

The tree crops, grown under field conditions are subjected to numerous nutrients deficiencies which influence the tree growth, tissue composition, fruit production and quality. Nutritional deficiencies are closely associated with the poor plant growth, fruit set, heavy fruit drop, inferior quality of produce. The average productivity of fruits in India is low as compared to many fruit going countries in the world. The area under guava in India is 235.6 thousand ha and production is 3198.3 thousand metric tonnes with a productivity of 13.6 metric tonnes/ha. Micronutrient plays an important role in production and its deficiency leads in lowering the productivity (Singh, 2001). 
Guava is rich source of vitamin C, vitamin A, vitamin B12 (Riboflavin) and minerals like calcium, phosphate and iron. The vitamin $\mathrm{C}$ content of Guava fruit is $212 \mathrm{mg} / 100 \mathrm{~g}$ and pectin content $(1.15 \%)$. Zinc deficiency results in interveinal chlorosis, formation of little leaves and restricted internodes leading to "rosette".

Much of interest in common guava has been due to its delightful taste and flavour. It is the fruit that has been often referred as "Apple of tropics." Bronzing in guava is a complex nutritional disorder.

When fruiting starts in a soil marginal in $\mathrm{P}$ and $\mathrm{K}$, the nutrients are mobilised from older leaves to the fruits, causing bronze coloured leaves which results in reduced photosynthate, transfer to the roots and reduced uptake. Spraying of $0.3 \%$ boric acid 10-15 days before flowering correct the deficiency.

In general, foliar applications of 0.5 per cent zinc sulphate and 0.4 per cent boric acid 10 to 14 days before flowering effectively eliminate the zinc and boron deficiencies. Hence present investigation was carried out to evaluate the micronutrient mixture formulation in guava on growth, yield and quality.

\section{Materials and Methods}

The experiment was conducted at Central Farm, Department of Fruit crops, Horticultural \& Research Institute, Periyakulam during 2018-2019. The experimental site was fairly uniform with gentle slope. The soil was red soil, sandy loam in texture, and having good drainage. The experiment was conducted on wellestablished orchard of 3 years old Lucknow 49 guava trees which are planted at $3.0 \mathrm{x}$ $1.5 \mathrm{~m}$ spacing.
The experiment was laid out in Factorial Randomized Block Design (FRBD) with five treatments replicated four times with two different grades.

The treatments comprised of $\mathrm{T}_{1}$ as $\mathrm{RDF}+$ Enriched MN Mixture (Soil) @ 2kg/tree, $\mathrm{T}_{2-}$ $\mathrm{RDF}+$ Foliar spray of MNM@0.3\%, $\mathrm{T}_{3}-\mathrm{RDF}$ + Enriched MN Mixture (Soil)@2kg/tree + Foliar spray of MNM@0.3\%, $\mathrm{T}_{4}-$ Farmers practice (300:200:200g Urea, Super Phosphate, potash/tree), $\mathrm{T}_{5^{-}}$RDF (Without MNM) The foliar application of these treatments was made at three times of new flush, 30 and 60 days after flowering.

\section{Results and Discussion}

The soil is sandy loam with deep red in loam with irugur series. The initial soil was neutral in reaction with $\mathrm{pH}$ of 7.75 and $\mathrm{EC}$ of $0.34 \mathrm{dS}$ $\mathrm{m}^{-1}$. The available $\mathrm{N}$ was low $\left(248 \mathrm{Kg} \mathrm{ha}^{-1}\right)$, medium in available $\mathrm{P}\left(20.3 \mathrm{~kg} \mathrm{ha}^{-1}\right)$ (Table 1).

The available $\mathrm{K}$ was medium $\left(185 \mathrm{~kg} \mathrm{ha}^{-1}\right)$. The exchangeable $\mathrm{Ca}$ was $3.4 \mathrm{mg} / \mathrm{kg}$, exchangeable $\mathrm{Mg}$ of $5.2 \mathrm{mg} / \mathrm{kg}$ With regards to available micronutrients Fe was high 10.4 ppm, deficit in $\mathrm{Zn}(0.23 \mathrm{ppm})$, the available $\mathrm{Cu}$ and $\mathrm{Mn}$ was $0.80 \mathrm{ppm}$ and $0.46 \mathrm{ppm}$ respectively.

\section{Floral characters}

Application of RDF + Enriched MNM (Soil) @ $2 \mathrm{~kg} /$ tree + Foliar spray of MNM @ $0.3 \%$ $\left(\mathrm{T}_{3}\right)$ recorded Flowering (33.8\%), Fruit retention $(50.4 \%)$ while lowest was recorded in $\mathrm{T}_{4}$ ( Farmers practice) with $27.65 \%$ in flowering and fruit retention of $37.40 \%$ (Table 2).

As regards to grade, grade I recorded highest flowering and fruit retention with a value of $31.50 \%$ and $43.56 \%$ respectively. 
Among the combination of grade $\mathrm{x}$ treatment $\left(\mathrm{G}_{1} \mathrm{~T}_{3}\right)$ recorded the highest in flowers/ shoot $(34.8 \%)$ and fruit retention $(52.80 \%)$.

\section{Fruit characters}

Among the treatments, treatment $\left(\mathrm{T}_{3}\right) \mathrm{RDF}+$ Enriched MNM (Soil) @ 2kg/tree + Foliar spray of MNM @ $0.3 \%$ recorded highest Fruit diameter $(7.82 \mathrm{~cm})$ and yield $(43.7 \mathrm{t} / \mathrm{ha})$ while lowest was recorded in $\mathrm{T}_{4}$ (Farmers practice) with Fruit diameter $(6.82 \mathrm{~cm})$ and yield(19.6 t/ha) (Table 3).

As regards to grade, grade I recorded highest Fruit diameter and yield with a value of $8.37 \mathrm{~cm}$ and $36.94 \mathrm{t} / \mathrm{ha}$ respectively.. Among the combination of grade $x$ treatment $\left(\mathrm{G}_{1} \mathrm{~T}_{3}\right)$ recorded the highest in yield/ha of 47.9t/ha.

The production of more number of fruits per tree in this treatment could be due to zinc and iron which act as catalyst in the oxidation and reduction process and is also of great importance in the sugar metabolism thus increased the yield per tree. Increase in yield of guava fruits due to foliar application of micronutrients alone along with soil has been reported by several workers from different parts of country viz., Meena et al., (2005), Trivedi et al., (2012) which supports the results obtained in present investigation.

Minimum yield in control treatment is obvious and it may be due to non-availability of nutrients required for formation and development of fruits resulting in production of minimum number of fruits and less weight of fruit in turn leads to production of lowest yield in this treatment

\section{Quality analysis}

\section{TSS and reducing sugar}

The maximum TSS $\left(12.8^{0}\right.$ Brix $)$ and reducing sugars $(8.02 \%)$ was recorded in the treatment $\mathrm{T}_{3}$ (RDF + Enriched MNM (Soil) @ 2kg/tree + Foliar spray of MNM @0.3\%) while minimum values of these parameters were noticed in the control $\mathrm{T}_{4}$ (Farmers practice) with TSS (11.1 ${ }^{0}$ brix ) and reducing sugars $(6.52 \%) \quad$ while the other treatments shows the intermittent values (Table 4).

Table.1 Initial soil characteristics of experiment field

\begin{tabular}{|c|c|}
\hline Particulars & Value \\
\hline pH & 7.75 \\
\hline $\operatorname{EC}\left(\mathrm{dS} \mathrm{m}^{-1}\right)$ & 0.34 \\
\hline Organic carbon (\%) & 0.47 \\
\hline $\operatorname{Nitrogen}\left(\mathrm{kg} \mathrm{ha}^{-1}\right)$ & 248 \\
\hline Phosphorus (kg ha $\left.{ }^{-1}\right)$ & 20.3 \\
\hline Potassium(kg ha ${ }^{-1}$ & 185 \\
\hline Calcium(mg kg $\left.{ }^{-1}\right)$ & 3.4 \\
\hline Magnesium mg kg-1) & 5.2 \\
\hline Iron(ppm) & 10.4 \\
\hline Copper(ppm) & 0.80 \\
\hline Manganese(ppm) & 0.46 \\
\hline Zinc(ppm) & 0.23 \\
\hline
\end{tabular}


Table.2 Effect of micronutrient mixture on flowering and fruit retention of Guava

\begin{tabular}{|c|c|c|c|c|c|c|c|}
\hline \multirow[t]{2}{*}{ T.No } & \multirow[t]{2}{*}{ Treatment Details } & \multicolumn{3}{|c|}{ Flowering \% } & \multicolumn{3}{|c|}{$\begin{array}{c}\text { Fruit retention } \\
(\%)\end{array}$} \\
\hline & & $\mathrm{G}_{1}$ & $\mathrm{G}_{2}$ & Mean & $\mathrm{G}_{1}$ & $\mathrm{G}_{2}$ & Mean \\
\hline $\mathbf{T}_{1}$ & $\begin{array}{l}\text { RDF + Enriched } \\
\text { MNM@ 2kg/tree }\end{array}$ & 32.60 & 30.00 & 31.30 & 45.20 & 43.40 & 44.30 \\
\hline $\mathbf{T}_{2}$ & $\mathrm{RDF}+0.3 \%$ foliar spray & 31.40 & 28.30 & 29.85 & 41.20 & 39.60 & 40.40 \\
\hline $\mathbf{T}_{\mathbf{3}}$ & $\begin{array}{l}\text { RDF + Enriched } \\
\text { MNM@ } 2 \mathrm{~kg} / \text { tree } \\
+0.3 \% \text { foliar spray }\end{array}$ & 34.80 & 32.80 & 33.80 & 52.80 & 48.00 & 50.40 \\
\hline $\mathbf{T}_{4}$ & Farmers practice & 28.50 & 26.80 & 27.65 & 38.30 & 36.50 & 37.40 \\
\hline \multirow[t]{5}{*}{$\mathbf{T}_{5}$} & RDF without MNM & 30.2 & 28.5 & 29.35 & 40.3 & 38.2 & 39.25 \\
\hline & Mean & 31.50 & 29.28 & & 43.56 & 41.14 & \\
\hline & & $\mathrm{T}$ & $\mathrm{G}$ & $\mathrm{T} \times \mathrm{G}$ & $\mathrm{T}$ & G & $\mathrm{T} \times \mathrm{G}$ \\
\hline & SEd & 0.13 & 0.21 & 0.29 & 0.27 & 0.42 & 0.60 \\
\hline & $\mathrm{CD}(5 \%)$ & 0.28 & 0.45 & 0.63 & 0.58 & 0.91 & 1.29 \\
\hline
\end{tabular}

Table.3 Effect of micronutrient mixture formulation on fruit characters and yield in Guava

\begin{tabular}{|l|l|c|c|c|c|c|c|}
\hline T.No & Treatment Details & \multicolumn{3}{|c|}{ Fruit diameter(cm) } & \multicolumn{3}{c|}{ Yield (t/ha) } \\
\hline & & $\mathrm{G}_{1}$ & $\mathrm{G}_{2}$ & Mean & $\mathrm{G}_{1}$ & $\mathrm{G}_{2}$ & Mean \\
\hline $\mathbf{T}_{\mathbf{1}}$ & $\begin{array}{l}\text { RDF + Enriched MNM@ 2kg/ } \\
\text { tree }\end{array}$ & 8.54 & 6.32 & 7.43 & 43.20 & 32.00 & 37.60 \\
\hline $\mathbf{T}_{\mathbf{2}}$ & RDF+0.3\% foliar spray & 8.33 & 6.15 & 7.24 & 41.60 & 30.80 & 36.20 \\
\hline $\mathbf{T}_{\mathbf{3}}$ & $\begin{array}{l}\text { RDF + Enriched MNM @ 2kg/ } \\
\text { tree +0.3\% foliar spray }\end{array}$ & 8.99 & 6.65 & 7.82 & 47.90 & 39.50 & 43.70 \\
\hline $\mathbf{T}_{\mathbf{4}}$ & Farmers practice & 7.84 & 5.80 & 6.82 & 20.00 & 19.20 & 19.60 \\
\hline $\mathbf{T}_{\mathbf{5}}$ & RDF without MNM & 8.17 & 6.04 & 7.10 & 32.00 & 30.00 & 31.00 \\
\hline & Mean & 8.37 & 6.19 & & 36.94 & 30.30 & \\
\hline & & $\mathrm{T}$ & $\mathrm{G}$ & $\mathrm{T} \times \mathrm{G}$ & $\mathrm{T}$ & $\mathrm{G}$ & $\mathrm{T} \times \mathrm{G}$ \\
\hline & SEd & 0.06 & 0.10 & 0.14 & 2.31 & 3.66 & 3.42 \\
\hline & CD(5\%) & 0.14 & 0.22 & $\mathrm{NS}$ & 4.96 & 7.85 & 6.89 \\
\hline
\end{tabular}

Table.4 Effect of Micronutrient mixture formulation on quality characters in Guava

\begin{tabular}{|l|l|c|c|c|c|c|c|}
\hline T.No & Treatment Details & \multicolumn{3}{|c|}{ TSS } & \multicolumn{3}{c|}{ Reducing sugar\% } \\
\hline & & $\mathrm{G}_{1}$ & $\mathrm{G}_{2}$ & Mean & $\mathrm{G}_{1}$ & $\mathrm{G}_{2}$ & Mean \\
\hline $\mathbf{T}_{\mathbf{1}}$ & $\begin{array}{l}\text { RDF + Enriched MNM@ } \\
\text { 2kg/ tree }\end{array}$ & 14.3 & 10.6 & 12.4 & 8.58 & 6.34 & 7.46 \\
\hline $\mathbf{T}_{\mathbf{2}}$ & RDF+0.3\% foliar spray & 14.5 & 10.7 & 12.6 & 8.29 & 6.13 & 7.21 \\
\hline $\mathbf{T}_{\mathbf{3}}$ & $\begin{array}{l}\text { RDF + Enriched MNM@ } \\
\text { 2kg/ tree +0.3\% foliar spray }\end{array}$ & 14.8 & 10.9 & 12.8 & 9.22 & 6.82 & 8.02 \\
\hline $\mathbf{T}_{\mathbf{4}}$ & Farmers practice & 12.8 & 9.5 & 11.1 & 7.73 & 5.71 & 6.72 \\
\hline $\mathbf{T}_{\mathbf{5}}$ & RDF without MNM & 14.0 & 10.4 & 12.2 & 7.50 & 5.54 & 6.52 \\
\hline & Mean & 14.1 & 10.4 & & 8.26 & 6.11 & \\
\hline & & $\mathrm{T}$ & $\mathrm{G}$ & $\mathrm{T} \times \mathrm{G}$ & $\mathrm{T}$ & $\mathrm{G}$ & $\mathrm{T} \times \mathrm{G}$ \\
\hline & $\mathrm{SEd}$ & 0.11 & 0.17 & 0.24 & 0.46 & 0.72 & 1.02 \\
\hline & $\mathrm{CD}(5 \%)$ & 0.23 & 0.37 & $\mathrm{NS}$ & 0.98 & 1.02 & $\mathrm{NS}$ \\
\hline
\end{tabular}


Table.5 Effect of micronutrient mixture formulation on quality characters in Guava

\begin{tabular}{|c|c|c|c|c|c|c|c|}
\hline \multirow[t]{2}{*}{ T.No } & \multirow[t]{2}{*}{ Treatment Details } & \multicolumn{3}{|c|}{ Non Reducing Sugar\% } & \multicolumn{3}{|c|}{ Acidity (\%) } \\
\hline & & $\mathrm{G}_{1}$ & $\mathrm{G}_{2}$ & Mean & $\mathrm{G}_{1}$ & $\mathrm{G}_{2}$ & Mean \\
\hline $\mathbf{T}_{1}$ & $\begin{array}{l}\text { RDF + Enriched MNM@ } \\
2 \mathrm{~kg} / \text { tree }\end{array}$ & 6.77 & 5.01 & 5.89 & 0.41 & 0.55 & 0.48 \\
\hline $\mathbf{T}_{2}$ & RDF+0.3\% foliar spray & 6.47 & 4.79 & 5.63 & 0.43 & 0.59 & 0.51 \\
\hline $\mathbf{T}_{\mathbf{3}}$ & $\begin{array}{l}\text { RDF + Enriched MNM@ } \\
2 \mathrm{~kg} / \text { tree }+0.3 \% \text { foliar spray }\end{array}$ & 7.97 & 5.89 & 6.93 & 0.36 & 0.48 & 0.42 \\
\hline $\mathbf{T}_{4}$ & Farmers practice & 6.13 & 4.53 & 5.33 & 0.61 & 0.83 & 0.72 \\
\hline \multirow[t]{5}{*}{$\mathbf{T}_{5}$} & RDF without MNM & 6.27 & 4.63 & 5.45 & 0.53 & 0.71 & 0.62 \\
\hline & Mean & 6.72 & 4.97 & & 0.47 & 0.63 & \\
\hline & & $\mathrm{T}$ & $\mathrm{G}$ & $\mathrm{T} \times \mathrm{G}$ & $\mathrm{T}$ & $\mathrm{G}$ & $\mathrm{T} \times \mathrm{G}$ \\
\hline & SEd & 0.38 & 0.59 & 0.84 & 0.04 & 0.06 & 0.09 \\
\hline & $\mathrm{CD}(5 \%)$ & 0.81 & 0.98 & $\mathrm{NS}$ & 0.08 & 0.13 & $\mathrm{NS}$ \\
\hline
\end{tabular}

Among the grades, Grade I recorded highest value of $14.1^{\circ} \mathrm{brix}$ in TSS and 8.26 in reducing sugar\% when compared to grade II. The increased in nonproducing sugar and total sugar with micronutrients alone or in combination with other nutrients may be due to increased rate of photosynthesis and perceptible increase in sugar contents through the foliar feeding of zinc sulphate might be due to the active synthesis of tryptophan in the presence of zinc, the precursor of auxin which in turn causes an increase in rate of chlorophyll synthesis which ultimately accelerates the photosynthetic activity which accumulated more sugars in fruits. These findings are in agreement with Rawat et al., (2010). Zagade, 2017 reported that foliar application of zinc sulphate reduced the acid content in guava fruits.

\section{Non reducing sugar and acidity}

The maximum non reducing sugars $(6.93 \%)$ and lowest acidity $(0.42 \%)$ was recorded in the treatment $\mathrm{T}_{3}(\mathrm{RDF}+$ Enriched $\mathrm{MNM}$ (Soil) @ 2kg/tree + Foliar spray of MNM $@ 0.3 \%$ ) while minimum values of these parameters were noticed in the control $\mathrm{T}_{4}$ (Farmers practice) with non-reducing sugars of $5.33 \%$ and highest acidity $(0.72 \%)$ while the other treatments shows the intermittent values (Table 5). Among the grades, Grade I recorded highest value of 6.72 in nonreducing sugar\% and lowest acidity in Grade I with value of $0.47 \%$ when compared to grade II.

\section{References}

Meena, R.P., Mohammed, S. and Lakhawat, S.S. 2005. Effect of foliar application of urea and zinc sulphate on fruit quality and yield of pruned guava tree (Psidium guajava L.). Cv. Sardar under high density planting system. J. Hort. Sci., 11(2): 90-93.

Rawat, V., Tomar, Y.K. and Rawat, J.M.S. 2010. Influence of foliar application micronutrients on the fruit quality of guava Cv. Lucknow-49. J.Hill Agri., 1(1): 63-66.

Singh MV (2001) Evaluation of micronutrient status of difference agroecological zones of India. Fertiliser News 46(2): 25-42.

Trivedi, N., Singh, D., Bhadur, V., Prasad, V.M. and Collis, J.P. 2012. Effect of foliar application of zinc and boron on yield and quality of guava (Psidium guajava L.). Hort flora Res. Spect., 
1(3):281-283.

Zagade P.M. 2017. "Effect of foliar application of micronutrients on yield and quality of Guava (Psidium guajava
L.) Cv.Sardar." IOSR Journal of Pharmacy and Biological Sciences (IOSR-JPBS), vol. 12, no. 5, 2017, pp. 56-58.

\section{How to cite this article:}

Janaki, D., S. Prabhu, R. Poorniammal and Kannan, J. 2020. Effect of Micronutrient Mixture Formulation on Growth, Yield and Quality of Guava. Int.J.Curr.Microbiol.App.Sci. 9(05): 2017-2022. doi: https://doi.org/10.20546/ijcmas.2020.905.228 